\title{
$17^{\text {th }}$ Czech-Slovak-Polish Palaeontological Conference October 20-21, 2016, Kraków, Poland
}

\begin{abstract}
PREFACE
The conference as a platform for scientific exchange within Czech, Slovak and Polish palaeontological communities supports the development of palaeontological research in the Middle-East European region by maintaining contacts between different scientific centres including universities and research institutes, as well as museums and industry units. Various aspects of palaeontology and interdisciplinary studies based on traditional and innovated methods have been studied in cooperation with researchers of other European countries and representatives from other continents.

In 2016, this annual meeting came back to Kraków and for the first time took place at the Carpathian Branch of the Polish Geological Institute - National Research Institute. The organizers of the Conference: Andrzej Szydło, Małgorzata JugowiecNazarkiewicz, Małgorzata Garecka, Wojciech Granoszewski and Michał Krobicki, dedicated it to Professor Marian Książkiewicz, the first director of the Carpathian Branch. Marian Książkiewicz and his collaborators paid a close attention to the usefulness of palaeontological data for determining age and conditions under which the Carpathian rocks were formed.

More than eighty active participants presented almost 50 lectures and 40 posters based on ongoing studies, archival data, and museum collections during 10 scientific sessions. They show that fossils of various taxonomical affiliation and stratigraphical range (from the Cambrian to Present) play an importance role in the scientific research including taxonomy, biostratigraphy, palaeoecology, palaeoclimate and palaeogeography, and are also important for practical use in geological cartography, explorations of hydrocarbons and minerals, environmental protection, and reconstructing past climate changes. Some issues, especially those relating to taxonomy as well as environmental and thermal (climate) conditions stimulated by geotectonic and palaeogeographic reorganization or water-level changes, are presented in the special conference volume.

Zdeněk Vašíček and Ondřej Malek concerned with the so-called pseudothurmanniid ammonites of the Late Hauterivian, which dominate in the Neocomian deposits of the Krížna Nappe in the Strážov Mountains (Central Western Carpathians). The fossil ma-
\end{abstract}

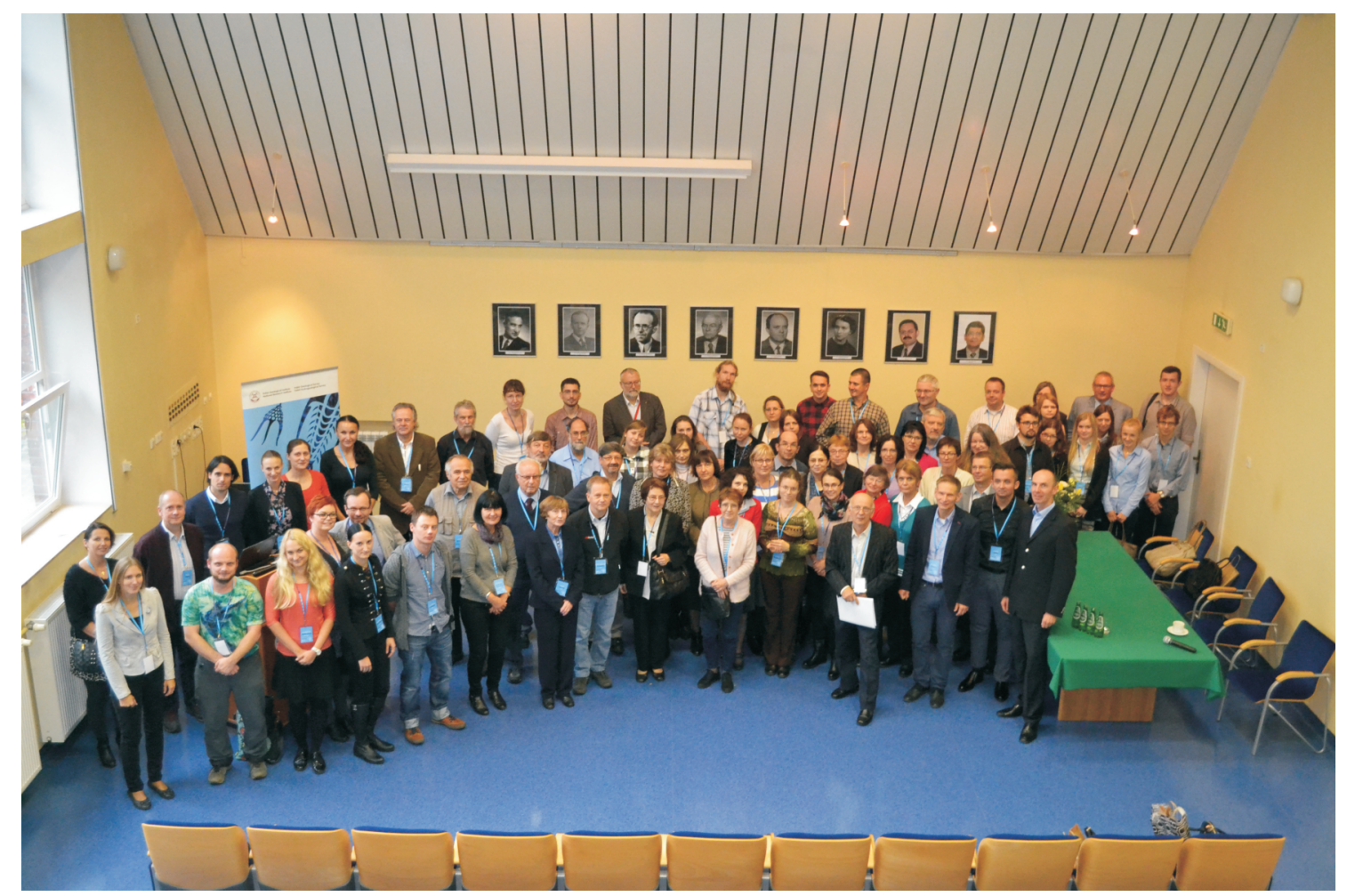


terial was collected by J. Michalík at the end of the $20^{\text {th }}$ century. Among the described ammonites there was a specimen classified as a new species and named Binelliceras michalíki.

Valentina S. Vishneskaya documented the Jurassic-Cretaceous boundary in Boreal Russia. In the study, radiolarians and other data (magnetostratigraphy) have been used as additional biomarkers for calibration of the boundary and correlation with the Tethyan Realm because Calpionella and calcareous nannoplankton are practically unknown in the study area. Consequently, the radiolarian biohorizons of Parvicingula haeckeli and $P$. khabakovi were regarded by the author as the major markers, while calcareous dinocysts (S. proxima) were proposed as the secondary ones.

Radek Vodrážka described new species (Guettardiscyphia ziti) of hexactinellid sponges from the Lower Turonian of the Bohemian Cretaceous Basin. This very remarkable taxon was classified more than one hundred years after the first note about its genus, and belongs to a highly variable faunal group closely related with rocky-coast facies spreading below the storm-wave base.

Weronika Baliniak and Ewa Malata presented a method of taxonomic classification based on thin sections of isolated specimens of planktic forms. The study refers to the uppermost Paleocene-Middle Eocene taxa from pelagic variegated marls of the Fore-Magura Unit in the Polish Outer Carpathians, showing SEM images, stereomicroscope photos of isolated specimens, and experimental thin sections, and discussing the systematics and stratigraphic ranges of the taxa. A review of thin sections shows that their diagnostic quality could have been higher if the specimens of particular species had been of similar sizes, with additional application of mechanical grounding of samples.

Finally, Barbara Olszewska and Andrzej Szydło reviewed foraminiferal and geochemical records from the Polish Outer Carpathians to reconstruct environmental stress in the northern Tethys during the Paleogene. The authors suggest that foraminifera were limited to low-diversified eutrophic assemblages or were mainly replaced by siliceous phytoplankton (radiolarians and diatoms) during periods of oxygen deficiency in a partly stratified basin. Changes in the biota took place under changing thermal conditions that reflect global events (KTBE, PTME, EEOC, TTE) in isolated parts the Paleogene basins. Under these conditions, certain minerals or rocks occasionally occurred during the Paleocene to Eocene (siderite, phosphates) and dominated in the Early Oligocene (silica).

Inviting you for interesting reading, we hope the conference, as a forum for discussions and presentations of new ideas and research methods, is of great importance for the development of palaeontology and regional geology, and will continue to expand in the future.

Andrzej Szydło and Tadeusz Marek Peryt 